OAK RIDGE

4. NATIONAL LABORATORY

MANAGED BY UT-BATTELLE

FOR THE DEPARTMENT OF ENERGY

\title{
Irradiation Effects on Phase-Separation Performance Using a Centrifugal Contactor in a Caustic-Side Solvent Extraction Process
}

\section{August 2001}

Prepared by

Joseph F. Birdwell, Jr., and Robert L. Cummings 


\title{
DOCUMENT AVAILABILITY
}

Reports produced after January 1, 1996 are generally available free via the U.S. Department of Energy (DOE) Information Bridge.

Web site http://www.osti.gov/bridge

Reports produced before January 1, 1996 may be purchased by members of the public from the following source.

\author{
National Technical Information Service \\ 5285 Port Royal Road \\ Springfield, VA 22464 \\ Telephone 703-605-6000 (1-800-553-6847) \\ TDD 703-487-4639 \\ Fax 703-605-6900 \\ E-mail info@ntis.fedworld.gov \\ Web site http://www.ntis.gov/support/ordernowabout.htm
}

Reports are available to DOE employees, DOE contractors, Energy Technology Data

Exchange (ETDE) representatives, and International Nuclear Information System (INIS) representatives from the following source.

Office of Scientific and Technical Information

P.O. Box 62

Oak Ridge, TN 37831

Telephone 865-576-8401

Fax 865-576-5728

E-mail reports@adonis.osti.gov

Web site http://www.osti.gov/contact.html

This report was prepared as an account of work sponsored by an agency of the United States Government. Neither the United States Government nor any agency thereof, nor any of their employees, makes any warranty, express or implied, or assumes any legal liability or responsibility for the accuracy, completeness, or usefulness of any information, apparatus, product, or process disclosed, or represents that its use would not infringe privately owned rights. Reference herein to any specific commercial product, process, or service by trade name trademark, manufacturer, or endorsement recommendation, or favoring by the United States Government or any agency thereof. The views and opinions of authors expressed herein do not necessarily state or reflect those of the United States Government of any agency thereof. 
ORNL/TM-2001-91

\author{
Chemical Technology Division
}

\title{
IRRADIATION EFFECTS ON PHASE-SEPARATION PERFORMANCE USING A CENTRIFUGAL CONTACTOR IN A CAUSTIC-SIDE SOLVENT EXTRACTION PROCESS
}

\author{
Joseph F. Birdwell, Jr. \\ Robert L. Cummins
}

Date Published: June 2001

\author{
Prepared for \\ the Office of Project Completion \\ Office of Environmental Management, U.S. Department of Energy \\ and \\ the Tanks Focus Area, Office of Science and Technology, \\ Salt Processing Program, U.S. Department of Encrgy \\ Prepared by \\ OAK RIDGE NATIONAL LABORATORY \\ Oak Ridge, Tennessee 37831-6285 \\ managed by \\ UT-BATTELLE, LLC \\ for the \\ U.S. DEPARTMENT OF ENERGY \\ under contract DE-AC05-00OR22725.
}

\footnotetext{
" Robotics and Process Systems Division
} 
The submitted manuscript has been authored by a contractor of the U.S. Government under contract DE-AC05-OR22725. Accordingly, the U.S.

Government retains a nonexclusive, royalty-free license to publish or reproduce the published form of this contribution, or allow others to do so, for U.S.

Government purposes. 


\section{CONTENTS}

LIST OF TABLES $\ldots \ldots \ldots \ldots \ldots \ldots \ldots \ldots$

LIST OF FIGURES $\ldots \ldots \ldots \ldots \ldots \ldots \ldots$ vii

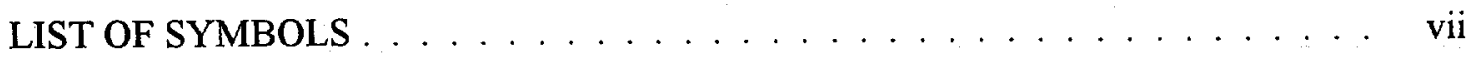

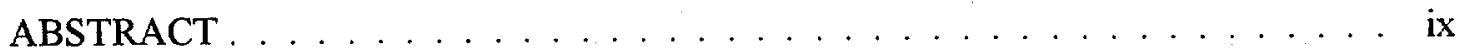

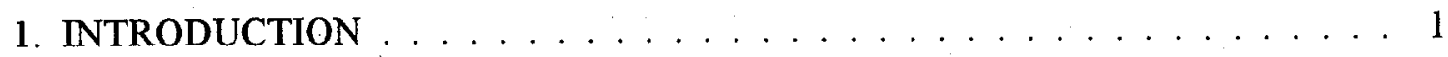

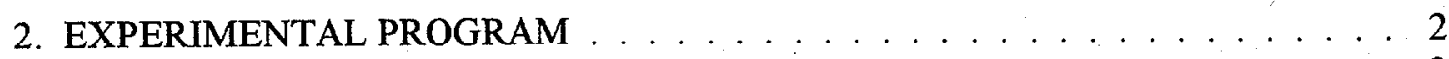

2.1 Description of Equipment . . . . . . . . . . . . . 2

2.1.1 Centrifugal Contactor . . . . . . . . . . . . 2

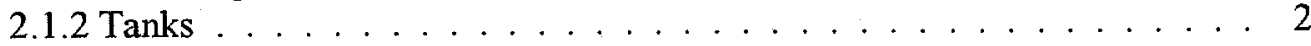

2.1.3 Mixing-Tank Agitator . . . . . . . . . . . . . . . . . . . . 3

2.1 .4 Pump . . . . . . . . . . . . . . . . . 3

2.1 .5 Sight Glasses . . . . . . . . . . . . . . . . 3

2.2 Chemicals Used . . . . . . . . . . . . . . . . . 3

2.3 Experimental Procedures . . . . . . . . . . . . . . . . 8

2.3.1 Cold Checkout . . . . . . . . . . . . . . . . 8

2.3.2 Preparations for Irradiation Test . . . . . . . . . . . . . . . . . 9

2.3.3 Irradiation Test Procedure-Stripping Mode . . . . . . . . . . . . . . . . 11

2.3.4 Recovery of Cesium from Stripping-Mode Test . . . . . . . . . . . . . 13

2.3.5 Post-Stripping Flush of Irradiation System . . . . . . . . . . . . . 14

2.3.6 Extraction-Mode Test Procedure . . . . . . . . . . . . . . . 15

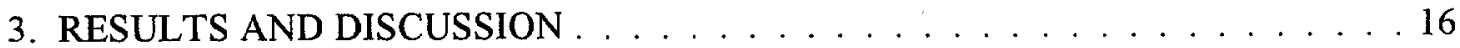

3.1 Stripping-Mode Irradiation Test . . . . . . . . . . . . . . . . . 16

3.1.1 Phase-Separation Performance . . . . . . . . . . . . . . 16

3.1.2 Distribution Ratio Results . . . . . . . . . . . . . . . . . . . 17

3.1.3 Solvent Degradation Results-Strip-Mode Testing . . . . . . . . . . . 18

3.1.4 Maximum Throughput Determination Using Irradiated Solvent-

Stripping Condition . . . . . . . . . . . . . . . . . . 19

3.2 Extraction-Mode Irradiation Test . . . . . . . . . . . . . . . . 20

3.2.1 Phase-Separation Performance . . . . . . . . . . . . . . 20

3.2 Cesium Distribution Results . . . . . . . . . . . . . . . . 20

3.2.3 Solvent Degradation Results-Extraction Testing . . . . . . . . . . . . . 21

3.2.4 Maximum Throughput Determination Using Irradiated Solvent-

Extraction Condition . . . . . . . . . . . . . . . . . 22

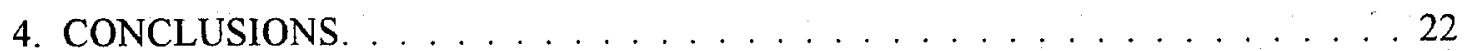

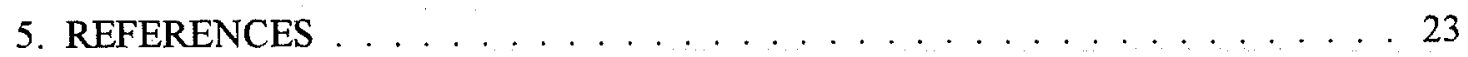

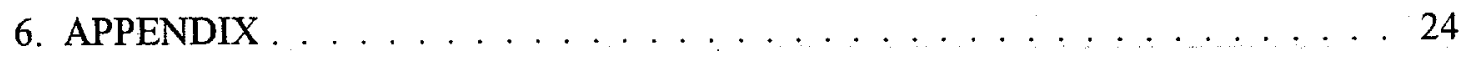




\section{LIST OF TABLES}

Table

Page

1 Key dimensions of CINC model V-2 $(5-\mathrm{cm})$ centrifugal contactor . . . . . 7

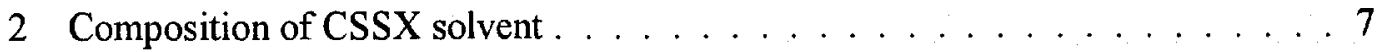

3 Activity and duration parameters for irradiation tests . . . . . . . . 11

4 Results from stripping-mode gravity settling observations . . . . . . . . 17

5 Cesium distribution results from stripping-mode irradiation test . . . . . . . . 18

6 Analytical results for solvent samples from stripping-mode irradiation . . . . . . 19

7 Results from extraction-mode gravity settling observations . . . . . . . . . . 21

8 Cesium distribution results from extraction-mode irradiation test . . . . . . . 21

9 Analytical results for solvent samples from extraction-mode irradiation. . . . . . 22 


\section{LIST OF FIGURES}

Figure $\quad$ Page

1 Schematic showing equipment for irradiation loop testing . . . . . . . 3

2 Photograph of irradiation test loop prior to placement in a hot cell . . . . . . 4

3 Cross section of centrifugal contactor rotor, with key dimensions indicated . . . 5

\section{LIST OF SYMBOLS}

$\mathrm{D}_{\mathrm{Cs}} \quad$ Distribution coefficient for desium (ratio of organic-phase cesium concentration to aqueous-phase concentration)

DF dccontamination factor

gc gravity acceleration constant

$\mathrm{N}_{\mathrm{Di}}$ dispersion number, a dimensionless quantifier of dispersion separation behavior

O/A ratio of organic-phase (solvent) flow rate to aqueous-phase flow rate

ppm parts per million expressed as mass per volume (e.g., mg/L)

$t_{b} \quad$ time required for dispersed, immiscible phases to separate, $s$

z height of a band of dispersed, immiscible phases 


\begin{abstract}
A test program has been conducted to determine the extent to which irradiation of a calixarene-based cesium extractant affects separation of the organic (solvent) phase from aqueous solutions with which it is contacted in a prototype extraction flowsheet. A caustic-side solvent extraction process, known as CSSX, has been developed for the selective removal of cesium from wastes generated by the processing of irradiated nuclear reactor fuels. This process consists of a cascade of mass transfer stages in which cesium is transferred from an aqueous feed into the CSSX extractant (BOBCalixC6), the extract is scrubbed with $0.05 \mathrm{M}$ nitric acid to remove coextracted elements, and the solvated cesium is stripped (or back-extracted) into $0.001 \mathrm{M} \mathrm{HNO}_{3}$. Removal of cesium from stored waste supernatants is desirable as a means of segregating highactivity cesium-137 $\left({ }^{137} \mathrm{Cs}\right)$ from the solution, thereby reducing the volume of material that must be processed and disposed of as high-level waste. The CSSX process is one of three cesium removal technologies currently being considered for deployment for treatment of wastes that are stored at the U. S. Department of Energy's (USDOE's) Savannah River Site (SRS).

The irradiation tests described in this report were designed to simulate the effect of 2 years of continuous solvent irradiation under conditions present in the stripping and extraction sections of the CSSX cascadc. Stated simply, the irradiation tests consisted of continuously mixing an aqueous process solution (either simulated SRS waste supernatant or dilute nitric acid) with the CSSX solvent. The aqueous solutions used in testing were spiked with ${ }^{137} \mathrm{Cs}$ at known activity levels. Test durations were determined based on the activity levels in the experiment and the estimated solvent exposures to radionuclides in a full-scale CSSX facility.

For most of the test period, CSSX solvent and the spiked aqueous solution were continuously agitated in a small mixing tank located inside a hot cell. Periodically, the dispersed phases from the mixing tank were pumped to a sight glass that had been installed in the test system. Phase separation by gravity settling was evaluated at intervals during testing, and the time required for separation was measured as a means of quantifying changes in separation behavior as the cumulative radiation dose increased. At the same intervals, the dispersion from the mixing tank was processed in a 5-cm centrifugal solvent extraction contactor to evaluate phase-separation performance under the effect of increased centrifugal force ( $>300$ times gravity). Effluent streams from the contactor were collected in sight glasses, both to examine the effluents for crossphase contamination and to obtain samples for chemical analysis. Organic samples were contacted with dilute nitric acid to remove cesium, thereby halting the irradiation process. These samples were assayed for the various solvent components and were also analyzed for a modifier radiolysis product to quantify solvent degradation.

In an effort to obtain the maximum data return from the irradiation test, aqueous samples collected at intervals during the test were gamma-counted to determine cesium concentrations. Using the results and the known activity levels at the start of each irradiation cycle, the organicphase cesium concentrations were determined by subtraction. The resulting organic- and aqueous-phase cesium concentrations were then used to calculate distribution ratios (i.e., D values) under CSSX extraction and stripping conditions. The determination of $D$ values was not a principal objective of the test effort, and the experiments were not designed to permit precise $\mathrm{D}_{\mathrm{CS}}$ determinations. As a consequence, the equipment and techniqucs availablc for obtaining data needed to calculate $\mathrm{D}$ values did not provide the level of precision needed to produce consistently accurate results. D values calculated from the data obtained in the reported work should be viewed as approximations that serve as qualitative indicators of changes in cesium partitioning in response to solvent irradiation.

The centrifugal contactor is the apparatus of choice for accomplishing both solute transfer and phase separation in the CSSX process. Selection of a centrifugal contactor having a 5-cmdiam rotor was based on the ability of devices of this size to provide processing throughputs
\end{abstract}


appropriate for a potential future engineering-scale demonstration of the CSSX process. In addition, results from prior contactor development and demonstration activities indicate that information obtained from performance characteristics of $5-\mathrm{cm}$ contactors can be scaled to larger (i.e., full-scale) centrifugal contactor cascades with a high level of confidence.

In both extraction and stripping modes, phase-separation times under the gravity-settling condition increased from the initial observation (i.e., the no-irradiation condition) to the final observation, but the increase was not sufficient to affect phase separation in the centrifugal contactors.

Centrifugal-contactor phase separations were performed at flow rates that were 75 to $80 \%$ of the maximum capacity for the subject application, based on out-of-cell throughput tests. At no point during the irradiation test was cross-phase contamination observed in either of the contactor effluent streams. Results of solvent sample analyses indicate no formation of the solvent modifier radiolysis product, 4-sec-butylphenol, during either phase of irradiation testing.

Distribution results obtained from the stripping-condition irradiation test were unacceptably high at all sample intervals, but trended downward as the test progressed. Bccause of this trend, it is probable that the $\mathrm{D}$ values obtained during stripping were high due to retention of waste simulant solution from cold checkout testing. This conclusion is supported by higher-thannormal $\mathrm{pH}$ values in the aqueous samples collected during the stripping phase of the irradiation test. Since the trend was evident throughout the stripping irradiation test, the contamination was probably present inside infrequently used sections of the test loop, including tubing in the vicinity of the contactor and the contactor itself.

Distribution ratio values under extraction conditions were higher than expected, based on reported values. Unlike the stripping-phase results, the ratios under extraction conditions exhibited no trend as the test progressed. Significant scatter in the extraction D values was apparent.

Based on the test results, irradiation of the CSSX solvent under conditions simulating 2 years of exposure may have an affect on phase separation under normal gravity. However, the magnitude of the change is not great enough to result in unacceptable phase-separation performance by centrifugal contactors operating at high centrifugal-force levels. 


\section{INTRODUCTION}

Tests to determine the effect of internal solvent irradiation on phase separation using a centrifugal solvent extraction contactor have been completed. Irradiation testing was performed in two phases. In the first phase, the solvent was irradiated under conditions (i.e., volumetric flow ratio, solution compositions) applicable to the stripping section of a CSSX cascade. In the second phase, the CSSX solvent was contacted with simulated SRS tank waste supernatant at conditions being proposed for the extraction section of the CSSX process.

In each phase of irradiation testing, the organic (solvent) phase and the appropriate aqueous solution were continuously mixed by mechanical agitation so that a dispersion of the two solutions was created and maintained. Periodically, the dispersion was pumped from the mixing tank to a single, $5-\mathrm{cm}$ centrifugal contactor to evaluate phase separation under the effect of high- $g$ (approximately 360-times-gravity) centrifugal force. Effluent streams from the contactor were collected in sight glasses that had been installed in the discharge lines, where they were inspected for cross-phase contamination. Before solutions were returned from the contactor sight glasses to the mixing tank, samples of the aqueous and organic contactor effluents were collected. The aqueous-phase samples were analyzed for cesium concentration by gamma counting. Immediately after collection, the organic-phase samples were contacted twice with $0.001 \mathrm{M}$ $\mathrm{HNO}_{3}$ to remove cesium in order to halt internal irradiation of the samples. These samples were assayed for extractant, phase modifier, and trioctylamine content and were also analyzed for the presence of 4-sec-butylphenol (a primary radiolysis product of the phase modifier). Because a small volume of aqueous entrainment in the organic effluent could settle in the tubing located below the sight glass, the organic effluent sample (collected from the bottom of the organic sight glass) was examined for entrainment prior to sample stripping.

At each contactor test interval, a volume of the dispersed material in the mixing tank was collected in a sight glass that had been installed in a recycle loop with the tank. The height of the material in the sight glass and the time required for the dispersion to separate by gravity settling were recorded in order to track the phase-separation performance as a function of radiation exposure.

After each phase of irradiation testing, procedures for recovering cesium from the experiment for use in non-CSSX-related testing were performed. Although outside the scope of the test plan, these operations were undertaken as a means of minimizing personnel radiation exposures during operations that required opening of the test cell (e.g., sample removal and equipment maintenance). Observations and results from these operations will be included in another report. 


\section{EXPERIMENTAL PROGRAM}

\subsection{DESCRIPTION OF EQUIPMENT}

All tests described in this report were performed using the equipment configuration shown in Figs. 1 and 2. Key components in the test loop were a $5-\mathrm{cm}$ centrifugal contactor; four stainless steel tanks; a positive displacement metering pump; three sight glasses; and a variable-speed, impeller-type agitator.

\subsubsection{Centrifugal Contactor}

A centrifugal solvent extraction contactor, obtained from CINC, Inc. (Carson City, NV) as a standard-design item (model V-2), was used in the test loop. The "5-cm" designation applied to the contactor throughout this report refers to the outside diameter of the contactor rotor. The contactor was equipped with a $110-\mathrm{V} \mathrm{AC}$, single-phase motor that was controlled by a variablefrequency drive. The drive frequency was controllable in $0.1-\mathrm{Hz}$ increments, corresponding to speed increments of approximately $6 \mathrm{rpm}$. The maximum frequency of the drive controller was $100 \mathrm{~Hz}$, which corresponds to a nominal rotor speed of $6000 \mathrm{rpm}$. All wetted contactor components had been fabricated from $316 \mathrm{~L}$ stainless steel, TFE Teflon ${ }^{\circledR}$, or TFE-encapsulated Viton ${ }^{\circledR}$. Contactor dimensions affecting throughput are listed in Table 1. A drawing of a contactor rotor in cross section, with kcy dimensions indicated, is presented in Fig. 3.

Table 1. Key dimensions of CINC model V-2 (5-cm) centrifugal contactor

\begin{tabular}{llcc}
\hline Designation & Description & $\begin{array}{c}\text { Dimension } \\
\text { (in.) }^{a}\end{array}$ & $\begin{array}{c}\text { Dimension } \\
\text { (mm) }\end{array}$ \\
\hline RSA & Aqueous weir radius & 0.4875 & 12.383 \\
RSO & Organic weir radius & 0.408 & 10.355 \\
RT & Rotor inlet radius & 0.200 & 5.076 \\
RU & Underflow radius & 0.875 & 22.208 \\
RC & Outside underflow radius & 0.938 & 23.807 \\
BO & Height of separating zone & 4.190 & 106.345 \\
BA & Height of aqueous channel & 0.400 & 10.152 \\
HAO & Height between weirs & 0.668 & 16.954 \\
DRC & Rotor/housing gap radius & 0.250 & 6.345 \\
& & & \\
THETA & Angle between underflows & $38^{\circ}$ & \\
\hline
\end{tabular}

${ }^{a}$ Except as indicated. 


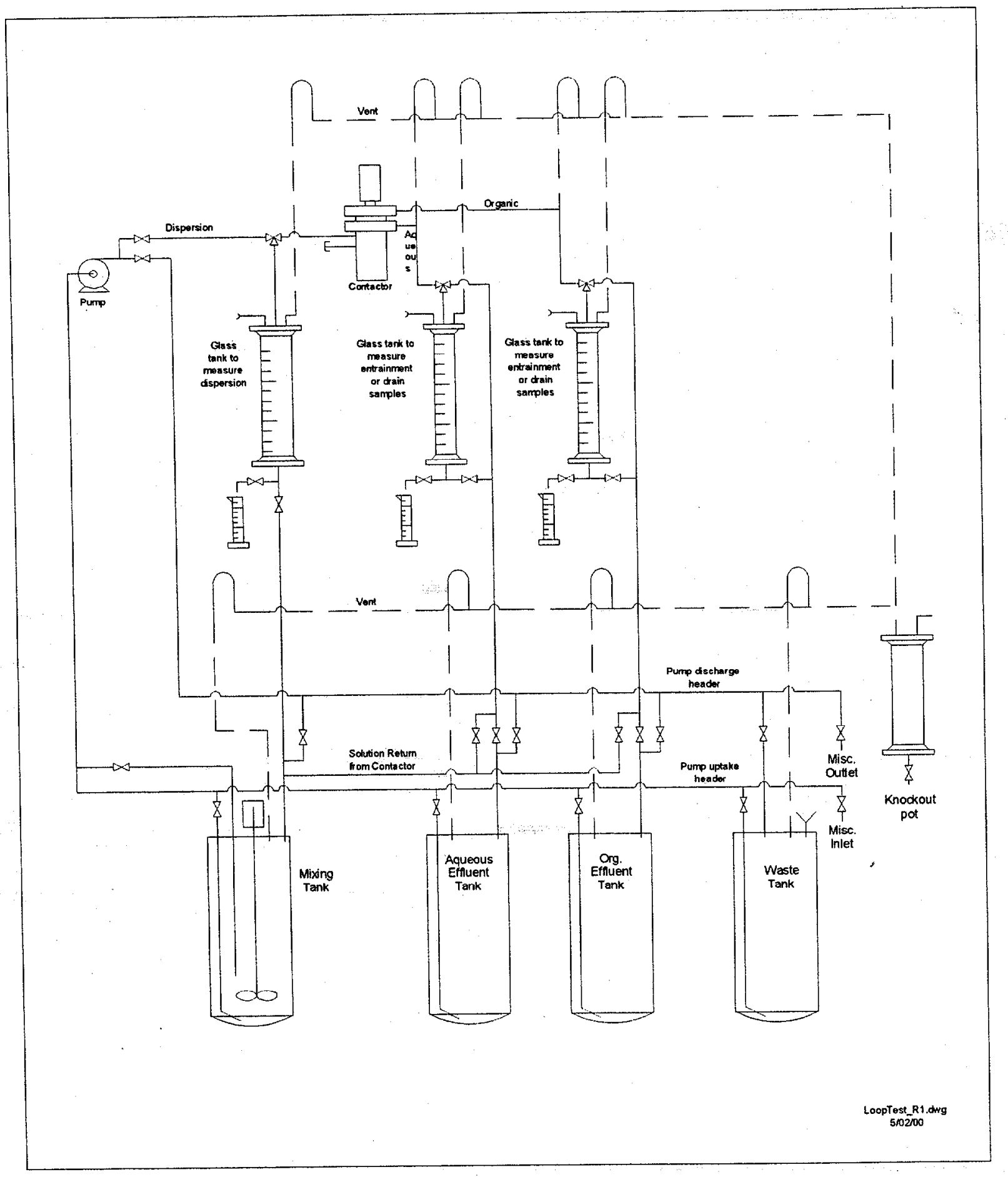

Fig.1. Schematic diagram showing equipment for irradiation loop testing. 


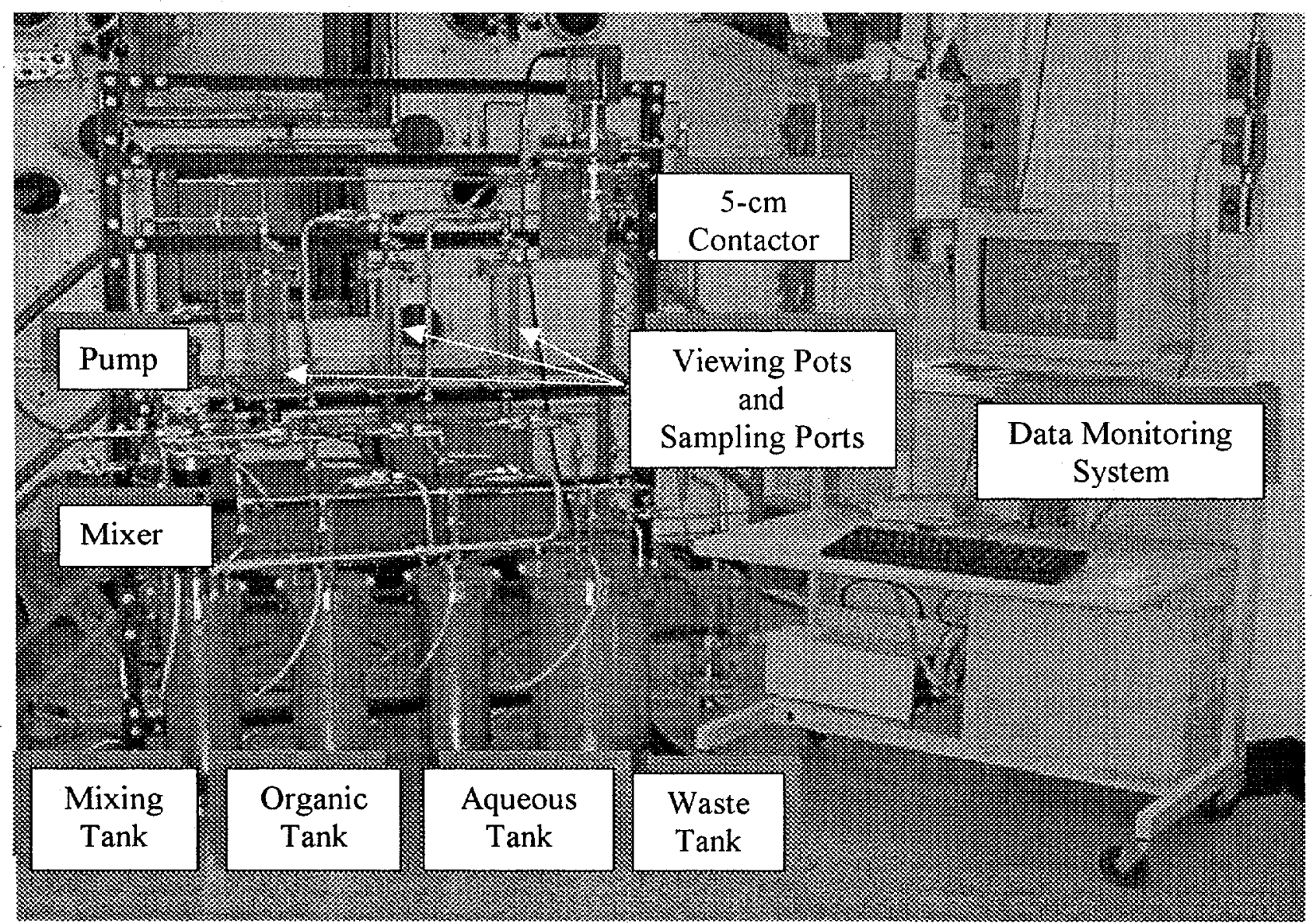

Fig. 2. Photograph of irradiation test loop prior to placement in a hot cell. 


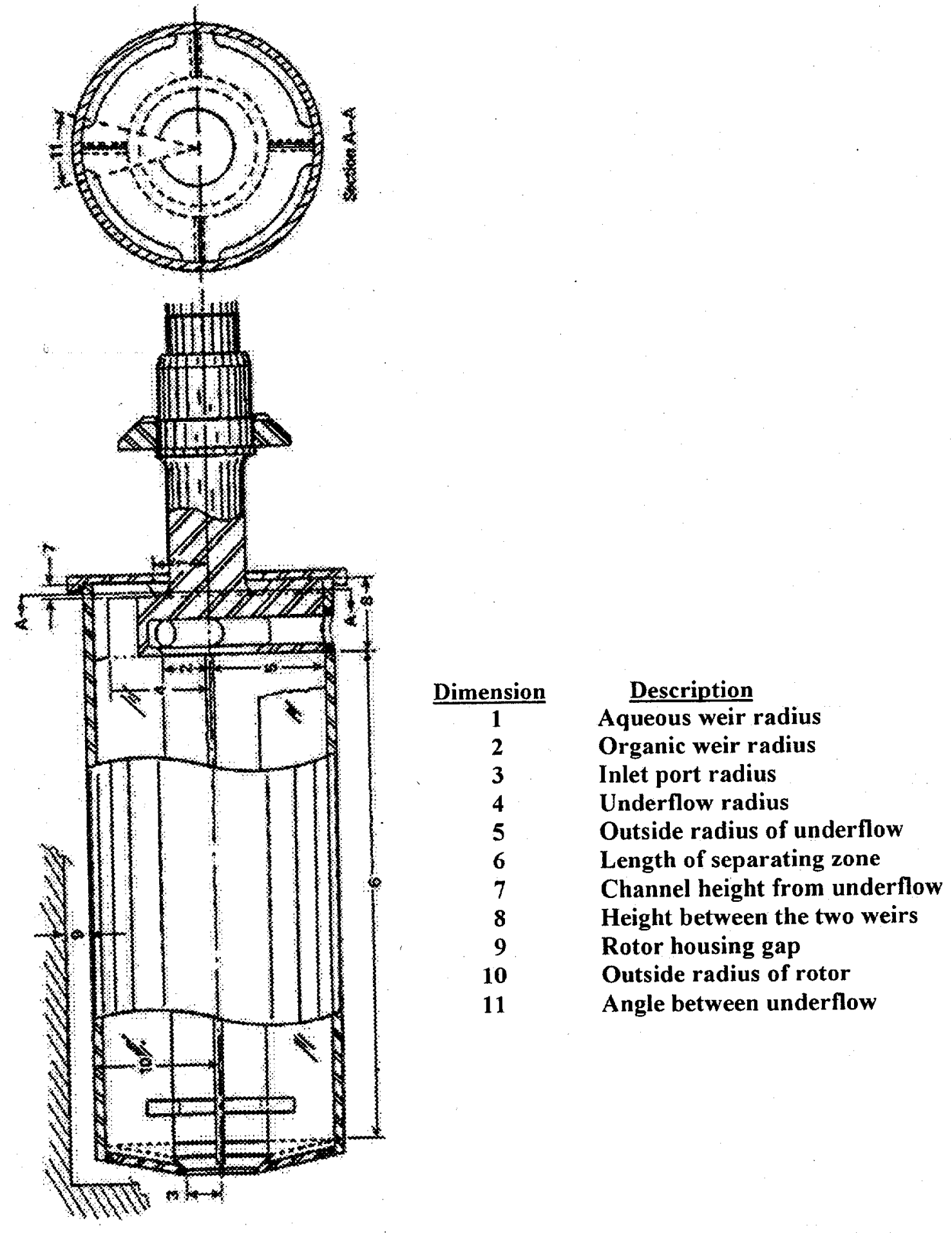

Fig. 3. Cross section of centrifugal contactor rotor, with key dimensions indicated. 


\subsubsection{Tanks}

The test loop utilized four stainless steel tanks, identified as the mixing tank, the aqueous effluent tank, the organic effluent tank, and the waste tank (see Fig. 1). All tanks were fabricated from $304 \mathrm{~L}$ stainless steel and had welded, dished bottoms. Nozzle and dip-tube penetrations on each tank were made only through a top-mounted flange; side and bottom penetrations were avoided to eliminate the risk of leakage from tank connections that might fail during testing.

The mixing, aqueous, and organic tanks had nominal, 6-in. outside diameters. The aqueous and organic tanks were each equipped with vent lines, two pressure taps (for level indication), two solution-return connections, and a pump-suction dip tube. The suction dip tube in each tank extended to within 0.125 in. of the bottom surface of the tank.

In addition to the connections described for the aqueous and organic tanks, the mixing tank was equipped with two pump-suction connections (one reaching to within 0.125 in. of the tank bottom and another ending approximately 4 in. higher), a thermocouple fitting, and a penetration for the agitator shaft. Four axial baffles, 12 in. long by 0.75 in. thick, were welded to the inner surface of the mixing tank at equal spacings.

The waste tank was a $10 \mathrm{in}$.-diam vessel having connections similar to those on the aqueous and organic tanks.

\subsubsection{Mixing Tank Agitator}

A Lightnin ${ }^{\circledR}$ general purpose (Model GP2) agitator equipped with a four-blade impeller with pitched blades was used to disperse the aqueous and organic solutions in the mixing tank. The maximum agitator speed achieved during cold testing was $1275 \mathrm{rpm}$, as indicated by a magneticpickup type of tachometer mounted adjacent to the agitator shaft.

\subsubsection{Pump}

All solution transfers were performed using a piston-type metering pump (Fluid Metering Inc., Model QV-2) with a maximum throughput of $1296 \mathrm{~mL} / \mathrm{min}$. The pump head was equipped with a 300 series stainless steel sleeve and a ceramic piston.

\subsubsection{Sight Glasses}

Three sight glasses, all of which were fabricated from 12-in. long borosilicate glass pipe and capped with stainless steel flange plates, were installed in the test loop. A 3-in.-diam sight glass, labeled "Glass tank to measure dispersion" in Fig. 1 (and referred to hereafter as G-M), was 
installed in parallel with the mixing tank and was used to evaluate gravity settling of the dispersion. During a cold checkout of the system, sight glass G-M was used to verify that mixing conditions in the mixing tank were adequate to thoroughly disperse the aqueous and organic phases. Sight glasses located respectively in the aqueous and organic discharge lines from the contactor (see Fig. 3) and referred to as G-A and G-O, respectively, were both fabricated from 2in.-diam glass pipe. G-A and G-O were used to collect effluents from the contactor for sampling; G-A was used to inspect the aqueous effluent for contamination with organic solution. As indicated in Fig. 1, all sight glasses were equipped with solution withdrawal lines, and valves and tubing were installed to permit bypassing of each sight glass without interruption of solution flow. Scales marked in millimeter increments were attached to each sight glass to permit determination of holdup volume. All sight glasses were calibrated for volume after fabrication of the test loop.

\subsection{CHEMICALS USED}

The CSSX solvent is a blend of the organic materials listed in Table 2. The calixarene extractant was developed by researchers at Oak Ridge National Laboratory specifically for the CSSX application.' During the cold checkout of the system, the organic phase was simulated using only Isopar ${ }^{\circledR} \mathrm{L}$ diluent.

Part of the solvent inventory in the irradiation testing had been used previously to determine the throughput limits for a 5-cm contactor under CSSX extraction, scrubbing, and stripping conditions. The remainder of the solvent had been used in single- and four-stage mass transfer tests with non-radioactive cesium. All solvent used in testing had been contacted previously with

Table 2. Composition of CSSX solvent.

\begin{tabular}{|c|c|}
\hline Component & $\begin{array}{c}\text { Concentration } \\
(M) \\
\end{array}$ \\
\hline $\begin{array}{l}\text { Calix(4)arene-bis-(tert-octylbenzo-crown-6 } \\
\text { (aka BOBCalixC6) }\end{array}$ & 0.01 \\
\hline $\begin{array}{l}\text { (2,2,3,3-Tetrafluoropropoxy)-3-(4-sec-butylphenoxy)-2-propanol } \\
\text { (aka Cs-7SB) }\end{array}$ & 0.50 \\
\hline Trioctylamine & 0.001 \\
\hline Isopar ${ }^{\circledR} \mathrm{L}$ & Balance \\
\hline
\end{tabular}


cesium. Prior to its use in the irradiation test loop, all solvent was stripped twice with $0.001 \mathrm{M}$ $\mathrm{HNO}_{3}$ at an organic/aqueous (O/A) flow ratio of 5.0 , was washed twice with $0.10 \mathrm{M}$ sodium hydroxide at an $\mathrm{O} / \mathrm{A}$ ratio of 1.0 , was contacted a third time with $0.001 \mathrm{MHNO}_{3}$, and was washed once with deionized water at an $\mathrm{O} / \mathrm{A}$ ratio of 5.0.

Scrub $\left(0.05 \mathrm{MHNO}_{3}\right)$ and strip $\left(0.001 \mathrm{MHNO}_{3}\right)$ aqueous solutions were formulated using $0.10 \mathrm{NHNO}_{3}$ (procured from J. T. Baker Co.) that was diluted with water that had been deionized using a Barnstead Nanopure $®$ filtration system. Sodium hydroxide solutions used to wash the solvent prior to its use in the test loop were formulated using sodium hydroxide pellets (ACS reagent grade; procured from the J. T. Baker Co.) that were dissolved in deionized water.

SRS waste supernatant simulant was formulated according to SRS procedure WSRC-RP2000-00361, Rev. 0, and had the composition listed in that document for "average" SRS supernatant simulant. ${ }^{2}$ The nominal cesium concentration in each simulant batch used in the tests reported here was $0.00014 M$.

\subsection{EXPERIMENTAL PROCEDURES}

For reporting purposes, the test effort has been divided into four tasks: cold checkout, extraction-mode irradiation, stripping-mode irradiation, and cesium recovery. The irradiation tests were the focus of the overall effort; information obtained from cold checkout and solute recovery operations is included only to supplement the findings from the irradiation tests.

\subsubsection{Cold Checkout}

Prior to transfer of the test loop into a hot cell for the irradiation test, a series of routine equipment checks were performed to verify the integrity of the system and to familiarize the operators with the equipment configuration. In addition, tests were performed to calibrate the level instruments in the four tanks installed in the system, to calibrate the metering pump and the three sight glasses, and to verify contactor and agitator operation. Since results of these routine tests were satisfactory and did not affect the interpretation of any of the results obtained from the test, no further description of this work is presented.

Checkout tests that did not address the hydraulic/mechanical integrity of the system or did not involve equipment calibration included

(1) an evaluation of the effectiveness of mixing tank agitation in producing a dispersion,

(2) an investigation of the ability to adequately flush the system between sets of test conditions, 
(3) a determination of the minimum solution heels remaining in the tanks after pumping, and

(4) a study of the comparative effects of initiating contactor operation with quiescent versus dispersed phases in the mixing tank.

Mixing efficiency was evaluated by agitating known volumes of organic and aqueous phases in the mixing tank, pumping the dispersion into sight glass G-M (with valves set to collect the dispersion), allowing the phases to separate, and determining whether the phase ratio in the G-M matched that in the mixing tank. Initial mixing tests were performed with equal volumes $(2 \mathrm{~L}$ each) of Isopar(B) $\mathrm{L}$ and $0.001 \mathrm{MHNO}_{3}$ in the mixing tank. Agitation was initiated at low speed, after which pumping was initiated in a recycle mode from the mixing tank to the pump, through sight glass G-M and back into the mixing tank. The pump rate and stroke were set to provide a flow rate of $0.5 \mathrm{~L} / \mathrm{min}$. Once flow had been established through the loop, the valve in the discharge line from G-M was closed and G-M was allowed to fill to approximately one-fourth of its total height. Pumping was then stopped, the phases were allowed to separate, and the relative volumes were recorded. In addition, the initial height of the dispersion band and the time required for the phases to separate were recorded. Measurements were repeated at several agitator speeds to determine the minimum value required to generate a dispersion having an $\mathrm{O} / \mathrm{A}$ ratio consistent with the ratio of solution volumes introduced into the mixing tank. Once a suitable speed had been determined, testing was repeated at various flow rates and liquid levels in G-M to determine the effects of these parameters on dispersion separation. Testing was also performed at $\mathrm{O} / \mathrm{A}$ ratios of 5.0 (equal to the flow ratio in the scrubbing and stripping sections of the CSSX cascade) and 0.308 (representing the flow ratio in the CSSX extraction section).

Phase-separation performance for the contactor was verified under various $\mathrm{O} / \mathrm{A}$ ratio and flow rate conditions. Initial contactor evaluations were conducted using Isopar ${ }^{\circledR} \mathrm{L}$ and $0.001 M$ $\mathrm{HNO}_{3}$ at an $\mathrm{O} / \mathrm{A}$ ratio of 1.0. To verify the ability to start contactor operation with dispersed feed during the irradiation test, the effect of feeding the contactor from the mixing tank under both initially agitated (dispersed feed) and initially quiescent (aqueous feed only) conditions was examined. In each case, feed was supplied to the contactor at the rate of $0.5 \mathrm{~L} / \mathrm{min}$.

As a final check, the Isopar ${ }^{\circledR}$ L used during the initial phase of system checkout was replaced with solvent that had been contacted first with SRS waste simulant at an O/A ratio of 0.308 and then with scrub solution $\left(0.05 \mathrm{MHNO}_{3}\right)$ at an $\mathrm{O} / \mathrm{A}$ ratio of 5.0. The effectiveness of mixing tank agitation in dispersing the solvent and strip acid at an O/A ratio of 5.0 (corresponding to the CSSX stripping condition) was verified using sight glass G-M in the method described previously. Similarly, phase separation using the centrifugal contactor was 
verified under stripping conditions using the preequilibrated solvent by operating the test loop (with the contactor included) in a constant recycle mode as before.

All contactor checkout tests were performed at a rotor speed of $3600 \mathrm{rpm}$.

\subsubsection{Preparation for Irradiation Test}

Following the cold checkout procedure and prior to transfer of the test loop into the hot cell, the system was drained of all solutions. The loop was transferred into Cell A, Building 4501, as a single, skid-mounted unit. Lead shielding, $1.5 \mathrm{in}$. thick, was placed around the sides of each of the tanks that were mounted on the skid. Electrical connections to the pump and contactor controller and to the data acquisition system were reestablished, as were the tubing connections to the differential pressure sensors used for level indication.

A source bottle containing $7.62 \mathrm{Ci}$ of ${ }^{137} \mathrm{Cs}$ as cesium chloride was opened and dissolved in demineralized water. The ${ }^{137} \mathrm{Cs}$ spike solution was prepared in Cell C, Bldg. 4501, which is one of three cells adjoining Cell $\mathrm{A}$. The spike solution had a final mass of $137.03 \mathrm{~g}$ and an approximate specific gravity of 1.0 at ambient temperature. The nominal cesium concentration in the spike solution from the ${ }^{137} \mathrm{Cs}$ source alone was $0.0203 \mathrm{M}$; the activity was $55.6 \mathrm{Ci} / \mathrm{L}$. Test durations and activity levels were determined based on a ${ }^{137} \mathrm{Cs}$ concentration of $1.42 \mathrm{Ci} / \mathrm{L}$ in the SRS waste stream.

CSSX flowsheet modeling calculations (provided by R. A. Leonard of Argonne National Laboratory; see Appendix A) served as the basis for determining the amounts of activity needed to simulate 2-year solvent irradiations at specific stage locations in the extraction, scrubbing, and stripping sections of the cascade. These calculations were also used to determine the total cesium inventories needed under the different test conditions. The cesium concentration profiles predicted were consistent with the current CSSX baseline flowsheet from which the O/A ratios used in checkout and irradiation testing were obtained. That baseline consists of 32 mass transfer stages (i.e., centrifugal contactors) arranged to provide 15 stages of cesium extraction, 2 stages of extractant scrubbing, and 15 stages of stripping (sometimes referred to as "back extraction"). Irradiation and cesium inventory conditions predicted at stages 15 (extraction), 17 (scrubbing), and 18 (stripping) of the cascade were selected for the irradiation test phases. The convention applied in the CSSX design was to begin numbering at the solvent feed stage. Using the predicted total cesium and ${ }^{137} \mathrm{Cs}$ levels at these points, combinations of ${ }^{137} \mathrm{Cs}$ spike masses and test durations needed to provide 2-year-equivalent solvent irradiations were calculated. Specific source masses and test durations for each of the three, planned irradiation phases were selected on 
the bases of manpower and ${ }^{137} \mathrm{Cs}$ availability. The unequal durations of the test phases reflect scheduling concerns pertaining to staffing during (1) periodic sampling and observation activities and (2) during changcovers between test phases. Selected spike masses and corresponding test durations, as well as the actual activities in the spike aliquots transferred to Cell $\mathrm{A}$ for the three planned test phases, are listed in Table 3.

It may be noted that previous sections of this report refer only to extraction- and strippingmode irradiation tests, while the previous paragraph described allocation of ${ }^{137} \mathrm{Cs}$ spike material for a scrub-mode test. Provision for scrubbing-mode irradiation was made on a contingency basis; scrub testing was to be performed if significant adverse changes in phase separation behavior were observed during either the extraction or the stripping tests. The scrubbing-phase irradiation was deleted from the test effort because (1) no significant change in phase separation was indicated under either of the other irradiation conditions and (2) phase separation is favored under scrubbing conditions relative to stripping separation (due to the slight differences between phase densities and ionic potentials).

In order to reach the stripping-mode cesium concentration target of $3.8 \mathrm{mM}$, a supplemental cesium source was prepared by dissolving $0.2723 \mathrm{~g}$ (stable) $\mathrm{CsNO}_{3}$ in demineralized water. The total volume of cesium solution generated, including the water used to rinse the weighing container, was $25 \mathrm{~mL}$. The supplemental solution was transferred into a 250 $\mathrm{mL}$ bottle that had been calibrated with $100-\mathrm{mL}$ and $200-\mathrm{mL}$ graduations. The small cesium container was rinsed once, and the rinse solution was poured into the $250-\mathrm{mL}$ bottle. The larger container, labeled "Bottle A," was transferred into Cell A with two, similarly calibrated bottles labeled " $B$ " and "C." No cold cesium supplement solutions were prepared for the extractionmode test.

After the bottles had been placed in Cell A, the cell door and access window were closed and ${ }^{137} \mathrm{Cs}$ spike solution was transferred from $\mathrm{Ccll} \mathrm{C}$ into the bottles via a metering pump and

Table 3. Activity and duration parameters for irradiation tests

\begin{tabular}{lccccc}
\hline Test mode & $\begin{array}{c}\text { Target activity } \\
(\mathrm{Ci})\end{array}$ & $\begin{array}{c}\text { Target spike } \\
\text { mass } \\
(\mathrm{g})\end{array}$ & $\begin{array}{c}\text { Test duration } \\
(\text { days })\end{array}$ & $\begin{array}{c}\text { Total } \\
\text { activity }^{{ }^{\prime}}{ }^{37} \mathrm{Cs} \\
(\mathrm{Ci})\end{array}$ & $\begin{array}{c}\text { Activity } \\
(\mathrm{Ci} / \mathrm{L})\end{array}$ \\
\hline Extraction & 1.84 & 33.18 & 27 & $1.83-1.84$ & 0.44 \\
Scrubbing & 2.41 & 41.46 & 18 & $2.07-2.09$ & 0.50 \\
Stripping & 3.46 & 62.39 & 11 & $3.52-3.53$ & 0.84 \\
\hline
\end{tabular}

${ }^{a}$ Ranges result from fluctuation in the scale reading during transfers. 
intercell tubing. The spike solution container in Cell $\mathrm{C}$ was placed on a scale during transfer so that fairly precise spike solution masses could be transferred to the three storage bottles in Cell A. After all remaining cesium spike solution had been transferred to bottle $\mathrm{C}$ (the scrubbing-mode spike aliquot), $0.001 \mathrm{M} \mathrm{HNO}_{3}$ was pumped through the intercell tubing to ensure that all the ${ }^{137} \mathrm{Cs}$ spike solution had been purged from the line.

\subsubsection{Irradiation Test Procedure-Stripping mode}

A 3.5-L volume of solvent that had been preequilibrated with cesium under extraction and scrubbing conditions (and was used in the final phase of the cold checkout) was transferred into the cell and poured into the mixing tank via a solution addition funnel. A $500-\mathrm{mL}$ volume of aqueous strip solution $\left(0.001 \mathrm{MHNO}_{3}\right)$ was then added to the tank.

The spike solution in bottle $A$, containing both stable and radioactive cesium, was diluted to a volume of $100 \mathrm{~mL}$ with $0.001 \mathrm{MHNO}_{3}$, and was then transferred to the mixing tank via a solution addition funnel. A second $100-\mathrm{mL}$ volume of $0.001 M \mathrm{HNO}_{3}$ was poured from a storage bottle in Cell $\mathrm{A}$ into bottle $\mathrm{A}$, which was emptied into the addition funnel to rinse any remaining spike solution from the bottle. Mixing at an indicated agitator speed of $800 \mathrm{rpm}$ was initiated immediately.

Agitation was continued for a period of $30 \mathrm{~min}$, after which the valves around the mixing tank were reset to permit transfer of dispersion from T-M to sight glass $\mathrm{G}-\mathrm{M}$, and pumping was initiated at a flow rate of $500 \mathrm{~mL} / \mathrm{min}$. Following a period of operation in continuous recycle, the valve in the discharge line from G-M was closed and the dispersed phases were collected in the sight glass. When the liquid level reached a suitable height in G-M, pumping was stopped and the dispersed phases were allowed to separate by gravity settling. Times required to fill the tank and for the interface to reach a stable position were recorded, as were the positions of the upper liquid surface and the phase boundary. Using sight-glass calibration data, the volumes of the two phases as well as the total liquid volume were determined. These results were then used to verify both the effectiveness of mixing (by determining the dispersion O/A ratio) and the pump rate. Under all test conditions, the entire visible height of liquid within the sight glass was in the dispersed condition when pumping into G-M was stopped.

After the flow rate and the O/A ratio had been verified, sight glass G-M was drained and the system valves were reset for continuous flow from the mixing tank to the contactor, through the contactor effluent sight glasses (G-A and G-O) and back into the mixing tank. Prior to starting 
the transfer pump, the contactor motor was turned on and the frequency was set to $60.3 \mathrm{~Hz}$ (corresponding to a rotor speed of $3600 \mathrm{rpm}$ ). Pumping was initiated and flow through the contactor in full recycle was maintained for a minimum of $10 \mathrm{~min}$ to ensure attainment of steady state. The valves in the discharge lines from $\mathrm{G}-\mathrm{A}$ and $\mathrm{G}-\mathrm{O}$ (the aqueous and organic sight glasses) were closed, and effluents were allowed to accumulate. Under stripping conditions, aqueous effluent was collected for approximately $30 \mathrm{~s}$ and organic effluent was collected for approximately $60 \mathrm{~s}$. At the end of the collection period, valves in the lines between the contactor and the two sight glasses were reset to direct effluent to the mixing tank, bypassing G-A and G-O. The solution inventory in G-A was then examined for evidence of an organic film or layer. If none was seen, a purge sample of solution in G-A was collected and returned to the mixing tank via a solution addition funnel. A second aqueous sample was collected for archival and eventual chemical analysis. A sample of solution from the lowermost section of $\mathrm{G}-\mathrm{O}$ was collected in a bottle and was moved by manipulator to the cell window to be examined for evidence of aqueous entrainment. If none was found, the sample was returned to the mixing tank and a second sample was collected from G-O for analysis.

To prevent changes in the $\mathrm{O} / \mathrm{A}$ ratio in the system during the test period, sample volumes removed from the test loop were proportional to the phase volumes present at the start of the test. Sample volumes collected during the stripping test phase were $10 \mathrm{~mL}$ of aqueous solution and 50 $\mathrm{mL}$ of organic solution. After collection of the organic sample, $50 \mathrm{~mL}$ of $0.001 \mathrm{MHNO}_{3}$ was added to the sample bottle. The bottle was capped, and the contents were agitated manually (using a manipulator) for $60 \mathrm{~s}$, followed by a 10-s hold period and an additional 60-s agitation interval. The dispersion formed was transferred to a separatory funnel, where it was allowed to separate for at least $5 \mathrm{~min}$. The aqueous phase was removed from the funnel and subsequently transferred to the waste tank. The organic phase was returned to the sample bottle and was again contacted with $50 \mathrm{~mL}$ of $0.001 \mathrm{MHNO}_{3}$. As before, the phases were agitated, the dispersion was transferred to a separatory funnel, the aqueous solution was transferred to the waste tank, and the organic sample was placed in a sample container for archival and analytical purposes. Based on a planned stripping test duration of 11 days and a desire to collect five sample sets (including the initial sampling), samples were collected and phase-separation observations were made at 2- to 3day intervals.

After each period of contactor operation, (1) the transfer pump was turned off, (2) the contactor was operated until both effluent flows ceased, and (3) the contactor motor was turned off. The contactor was then drained of residual solutions, which were returned to the mixing tank. 
After the fifth and final sampling under stripping conditions, the flow rate of dispersion to the contactor was increased incrementally from the normal $500-\mathrm{mL} / \mathrm{min}$ condition to determine the maximum throughput capacity of the unit when processing irradiated solvent at a rotor speed of $3600 \mathrm{rpm}$. Flow increases were to be stopped at the onset of cross-phase contamination in either effluent stream.

\subsubsection{Recovery of Cesium from Stripping-Mode Test}

Following completion of the stripping-mode test, a procedure was performed to recover ${ }^{137} \mathrm{Cs}$ from the aqueous solution used in the test. The decision to recover this material was based primarily on a desire to minimize the amount of activity present in Cell A. A secondary objective was to obtain ${ }^{137} \mathrm{Cs}$ for use in a non-CSSX test without having to open an additional ${ }^{137} \mathrm{Cs}$ source (thereby reducing personnel exposures). The recovered cesium was eventually used in demonstrations of cesium removal by precipiation with tetraphenylborate.

Cesium recovery from the stripping-mode irradiation was accomplished by setting the test loop valves so that aqueous effluent would be retained in aqueous sight glass G-A and the organic effluent would be collected in organic effluent tank. Agitation of the tank, which had been suspended following the fifth sampling operation, was resumed at the rate of $800 \mathrm{rpm}$. Contactor operation at $3600 \mathrm{rpm}$ was also resumed, and pumping from the mixing tank to the contactor was initiated. Sight glass G-A was allowed to fill with aqueous effluent, which was examined for organic contamination. The aqueous effluent was collected in bottles, after which the contactor was stopped and the contactor housing was drained. The solution collected from the contactor housing was separated; the aqueous phase collected was transferred to a sample bottle, and the organic phase was returned to the mixing tank. Valves were then reset to facilitate transfer of the solvent in the organic efluent tank to the mixing tank. Approximately $700 \mathrm{~mL}$ of $0.001 \mathrm{MHNO}$ was added to the mixing tank, and agitation was resumed. After about $15 \mathrm{~min}$, the system valves were reset for processing of the dispersion in the centrifugal contactor. As previously, the aqueous contactor effluent was collected in sight glass G-A prior to its transfer into storage bottles. The organic effluent was collected in T-O. At the end of the separation operation, the contactor rotation was terminated and the stripped solvent collected in tank T-O was transferred to the waste tank.

All aqueous solution collected from the stripping test was transferred from Cell A to Cell C using the intercell tubing that had initially been used to transfer ${ }^{137} \mathrm{Cs}$ spike solutions into Cell $\mathrm{A}$. 


\subsubsection{Post-Stripping Flush of Irradiation System}

Following the stripping-condition irradiation test, approximately $2 \mathrm{~L}$ each of $0.001 \mathrm{MHNO}_{3}$ and Isopar $(\mathbb{B}$ were placed in Cell $A$ via an access window. One liter of Isopar $(\mathrm{L}$ was transferred into the mixing tank via a solution addition funnel and line. Subsequently, agitation of the mixing tank at an impeller speed of $800 \mathrm{rpm}$ was initiated. Sample taps on the aqueous and organic sight glasses were opened, and the heels in the discharge lines from both were collected and transferred to the waste tank. Valves were then set to permit recycle from the mixing tank through the dispersion sight glass G-M and back into the mixing tank. After 10 min of recycle operation at a flow of $500 \mathrm{~mL} / \mathrm{min}$, pump operation was stopped, valves were reset to direct solution from the mixing tank to the waste tank, and pumping was resumed. Pumping was terminated when no additional decrease in the mixing tank was indicated by level instrumentation.

Approximately $1 \mathrm{~L}$ of strip acid was transferred into the mixing tank, and the system valves were reset to permit recycle of solution between the mixing tank and sight glass G-M. Pumping was initiated at the rate of $500 \mathrm{~mL} / \mathrm{min}$. After $5 \mathrm{~min}$ of operation in the recycle mode, contactor operation was initiated at $3600 \mathrm{rpm}$ and system valves were reset to direct flow from the mixing tank to the centrifugal contactor. Flows from the contactor were directed successively through sight glasses G-A and G-O and into the waste tank. Operation of the contactor, pump, and agitator was suspended when the discharge from the contactor stopped.

Approximately $1 \mathrm{~L}$ each of strip acid and Isopar ${ }^{\circledR} \mathrm{L}$ was placed in the mixing tank, and agitation was resumed. Initially, valves were aligned to direct flow from the mixing tank through sight glass G-M in continuous recycle. After a brief period of recycle, the discharge valve from G-M was closed and dispersion was allowed to fill G-M to a point near the upper flange. In order to flush the sample drain from G-M, a small volume of this material was removed from the drain tap and transferred to the waste tank. The remaining dispersion holdup in G-M was drained back into the mixing tank. Valves were then reset so that the flow was directed from the mixing tank to the centrifugal contactor, through the aqueous and organic sight glasses, and into the waste tank. When contactor effluent flows were observed, the valves in the sight glass discharge lines were closed, causing solutions to accumulate in G-A and G-O. When the levels in the sight glasses approached the top flanges, valves on the discharge line from each sight glasses was opened-allowing the rinse solution to flow into the waste tank. When flow from the contactor was stopped, operation of the contactor, pump, and agitator was also stopped. The contactor housing was then drained, and the contents were transferred to the waste tank. 


\subsubsection{Extraction-Mode Test Procedure}

With the exception of a few test parameters, procedures followed during extraction-mode irradiation were nearly identical to those performed under stripping conditions. Solution volumes placed in the mixing tank at the start of the extraction-mode irradiation test were $200 \mathrm{~mL}$ of ${ }^{137} \mathrm{Cs}$ spike solution, $990 \mathrm{~mL}$ of CSSX solvent, and $3010 \mathrm{~mL}$ of SRS waste supernatant simulant. The resulting $\mathrm{O} / \mathrm{A}$ ratio of 0.308 was equal to the value for the extraction section of the baseline CSSX flowsheet. The quantity of cesium in the ${ }^{137} \mathrm{Cs}$ was sufficient to achieve the target cesium inventory in the test system; no supplemental stable cesium was added.

Based on a planned test duration of approximately 28 days, the interval between separation evaluations and sample collections was 6 to 7 days. To maintain the desired O/A ratio throughout testing, one $20-\mathrm{mL}$ organic sample and one $65-\mathrm{mL}$ aqueous sample were collected at each sampling and observation interval. The flow rate during extraction-mode contactor testing was $810 \mathrm{~mL} / \mathrm{min}$ versus $500 \mathrm{~mL} / \mathrm{min}$ during the stripping test. The increased rate was based on contactor throughput test results that indicated greater contactor capacity under extraction conditions. Finally, because of the high distribution ratios expected under extraction conditions, organic samples collected during the extraction phase of testing were contacted twice with dilute $(0.001 \mathrm{M}) \mathrm{HNO}_{3}$ at an $\mathrm{O} / \mathrm{A}$ ratio of 5.0 to more effectively remove cesium from the sample.

\section{RESULTS AND DISCUSSION}

\subsection{STRIPPING-MODE IRRADIATION TEST}

\subsubsection{Phase-Separation Performance}

An initial attempt to determine the dispersion number under stripping conditions was made after filling sight glass G-M to the 23.8 graduation mark. Upon settling, it became apparent that the phase boundary was located below the upper surface of the bottom flange and thus was not visible. Therefore, the solution in the sight glass was allowed to drain back into the mixing tank, and the transfer of solution into G-M was repeated. The liquid level in the sight glass when pumping was terminated was located at the 3.8 graduation mark and the entire liquid column was observed to be in the dispersed condition. A stable interface was formed at the 23.8 graduation mark after settling for $4 \mathrm{~min} 15 \mathrm{~s}$. The dispersion sight glass was drained, and the mixing tank and G-M were operated in recycle for $5 \mathrm{~min}$ after which a second phase-separation observation 
was made. On the second measurement, liquid was accumulated to the 3.7 graduation mark, and a stable interface was formed at the 23.8 graduation after $5 \mathrm{~min}$ of gravity settling. As indicated in Table 4, the phase ratios determined from volumes in G-M were consistent with the phase volumes initially placed into the mixing tank.

Gravity settling data obtained at each sample interval were used to calculate dimensionless dispersion numbers, which quantify the separation behavior of a pair of immiscible solutions. The dispersion number is defined by the expression

$$
N_{D i}=\frac{1}{t_{b}} \sqrt{\frac{z}{g_{c}}},
$$

where $t_{b}$ is the break time in $\mathrm{s} ; z$ is the column height in $\mathrm{ft}$; and $g_{c}$ is the gravitational constant, $32.172 \mathrm{ft} / \mathrm{s}^{2}$. Phase separation times and dispersion numbers indicate a general trend toward poorer phase-separation performance as the test progressed. However, the values are somewhat scattered, reflecting the difficulty in determining the precise time required for phases to disengage when the process is viewed through a hot-cell window. Based on documented centrifugal contactor experience, ${ }^{3}$ the dispersion number values remained sufficiently high throughout the course of the test to obtain good phase separation at reasonably high contactor throughputs.

Table 4. Results from stripping-mode gravity settling observations.

\begin{tabular}{ccccccccc}
\hline $\begin{array}{c}\text { Sampling } \\
\text { interval }\end{array}$ & $\begin{array}{c}\text { Dispersion } \\
\text { volume, } \\
\mathrm{mL}\end{array}$ & $\begin{array}{c}\text { Solvent } \\
\text { volume, } \\
\mathrm{mL}\end{array}$ & $\begin{array}{c}\text { Aqueous } \\
\text { volume, } \\
\mathrm{mL}\end{array}$ & $\begin{array}{c}\text { O/A ratio } \\
\text { 1 }\end{array}$ & $\begin{array}{c}\text { Dispersion } \\
\text { band ht, in. }\end{array}$ & $\begin{array}{c}\text { Settling } \\
\text { time, } \mathrm{s}\end{array}$ & $\begin{array}{c}\text { Dispersion } \\
\text { no. }\end{array}$ \\
\hline 1 & 1056.5 & 872.0 & 184.5 & 4.73 & 9.54 & 255 & $6.17 \times 10^{-4}$ \\
2 & 1060.9 & 872.0 & 188.9 & 4.62 & 9.58 & 300 & $5.25 \times 10^{-4}$ \\
3 & 1052.2 & 893.8 & 158.4 & 5.64 & 9.50 & 270 & $5.81 \times 10^{-4}$ \\
4 & 1056.5 & 893.8 & 162.7 & 5.49 & 9.54 & 300 & $5.24 \times 10^{-4}$ \\
5 & 1060.9 & 893.8 & 167.1 & 5.35 & 9.58 & 390 & $4.04 \times 10^{-4}$ \\
\hline
\end{tabular}


As described in Section 2.3.2, dispersion was directed from the mixing tank to the centrifugal contactor and the contactor effluents were collected in sight glasses G-A and G-O. With the contactor operating at $3600 \mathrm{rpm}$, neither of the effluent volumes collected during the initial stripping-mode sampling evidenced any cross-phase contamination.

At all sampling intervals, the effluents from the centrifugal contactor were observed to be free of cross-phase contamination.

\subsubsection{Distribution Ratio Results}

Distribution ratios obtained during the stripping irradiation test were not favorable for cesium recovery from the extractant, but displayed steady improvement as the test progressed (see Table 5). Because of the direction of the trend in $\mathrm{D}_{\mathrm{Cs}}$ and the fact that strip-mode testing was performed immediately after completion of cold testing, it is suspected that a trace quantity of waste simulant could have remained in the system after cold testing. This conclusion is supported by aqueous-phase $\mathrm{pH}$ values, which consistently exceed the 3-to-3.5 $\mathrm{pH}$ range typically seen in the stripping section of the CSSX flowsheet. The presence of nitrate ion at increased concentration due to the retention of simulant in the system during stripping affects the extraction equilibrium in a manner unfavorable for cesium recovery, and is the most likely cause of the high $D_{C s}$ values shown in Table 5.

It is unlikely that the observed effect was due to contamination in the mixing tank since the contents of the mixing tank should have reached equilibrium quickly and remained in that state for the duration of the test. It is more likely that contamination was present in the contactor or associated tubing because this equipment is used only intermittently during testing:

Table 5. Cesium distribution results from the stripping-mode irradiation test.

\begin{tabular}{cccccccccc}
\hline $\begin{array}{c}\text { Sample } \\
\text { interval }\end{array}$ & $\begin{array}{c}\mathrm{Ci} / \mathrm{L}, \\
\text { Aqueous } \\
\text { phase }\end{array}$ & $\begin{array}{c}\text { Sample } \\
\text { dilution }\end{array}$ & $\begin{array}{c}\text { Corrected } \\
\text { activity, } \\
\mathrm{Ci} / \mathrm{L}\end{array}$ & $\begin{array}{c}\text { Aqueous } \\
\text { system } \\
\text { vol., } \mathrm{mL}\end{array}$ & $\begin{array}{c}\text { Solvent } \\
\text { volume, } \\
\mathrm{mL}\end{array}$ & $\begin{array}{c}\text { Total } \\
\text { aqueous } \\
\text { activity, } \\
\mathrm{Ci}\end{array}$ & $\begin{array}{c}\text { Total } \\
\text { solvent } \\
\text { activity, } \\
\mathrm{Ci}\end{array}$ & $\begin{array}{c}\text { Aqueous } \\
\text { sample } \\
\mathrm{pH}\end{array}$ & $\mathrm{D}_{\mathrm{Cs}}$ \\
\hline 1 & $2.97 \mathrm{E}-05$ & 117.37 & $3.49 \mathrm{E}-03$ & 700 & 3500 & $2.44 \mathrm{E}-03$ & $3.52 \mathrm{E}+00$ & 5 & $2.88 \mathrm{E}+02$ \\
2 & $4.59 \mathrm{E}-03$ & 130.42 & $5.99 \mathrm{E}-01$ & 690 & 3450 & $4.13 \mathrm{E}-01$ & $3.11 \mathrm{E}+00$ & 6 & $1.50 \mathrm{E}+00$ \\
3 & $8.92 \mathrm{E}-03$ & 107.53 & $9.59 \mathrm{E}-01$ & 680 & 3400 & $6.52 \mathrm{E}-01$ & $2.87 \mathrm{E}+00$ & 6 & $8.79 \mathrm{E}-01$ \\
4 & $8.65 \mathrm{E}-03$ & 106.04 & $9.17 \mathrm{E}-01$ & 670 & 3350 & $6.14 \mathrm{E}-01$ & $2.91 \mathrm{E}+00$ & 6 & $9.46 \mathrm{E}-01$ \\
5 & $1.22 \mathrm{E}-02$ & 98.37 & $1.20 \mathrm{E}+00$ & 660 & 3300 & $7.90 \mathrm{E}-01$ & $2.73 \mathrm{E}+00$ & 6 & $6.92 \mathrm{E}-01$ \\
\hline
\end{tabular}


The adverse effect of $\mathrm{pH}$ deviation due to waste solution carryover or insufficient $\mathrm{pH}$ adjustment during stripping had been observed previously in both single- and multi-stage mass transfer tests. The impact of this problem and the difficulty in recovering from its effects highlight the need for including sufficient scrubbing stages in the CSSX flowsheet to adjust the $\mathrm{pH}$ of the solvent entering the stripping section. In addition, these stages can act as a buffer in the event of process upsets that "push" the hydroxide-ion gradient toward the stripping section of the cascade.

\subsubsection{Solvent Degradation Results-Strip-Mode Testing}

Results of the solvent analyses indicate no formation of the modifier radiolysis product 4$s e c$-butylphenol or any significant change in the solvent composition as the test progressed. Results of the analyses are presented in Table 6.

\subsubsection{Maximum Throughput Determination Using Irradiated Solvent-Stripping Condition}

Following completion of the final sampling from the strip-mode test, a procedure was performed to determine the flow condition at which phase-separation performance using the $5-\mathrm{cm}$ contactor became inadequate. While a contactor speed of $3600 \mathrm{rpm}$ was maintained, organic flows were increased incrementally from an initial dispersion flow rate of $500 \mathrm{~mL} / \mathrm{min}(\mathrm{O} / \mathrm{A}=5)$ to a throughput of $800 \mathrm{~mL} / \mathrm{min}$ with no evidence of cross-phase contamination. Beginning at a

Table 6. Solvent sample analysis results from stripping-mode irradiation

\begin{tabular}{ccccc}
\hline $\begin{array}{c}\text { Sample } \\
\text { Interval }\end{array}$ & $\begin{array}{c}\text { Cs-7SB } \\
\text { (modifier) } \\
\text { concentration, } \\
M\end{array}$ & $\begin{array}{c}\text { BOBCalixC6 } \\
\text { concentration, } \\
M\end{array}$ & $\begin{array}{c}\text { Trioctylamine } \\
\text { concentration, } \\
m M\end{array}$ & $\begin{array}{c}\text { 4-sec-butylphenol } \\
\text { concentration, } \\
\text { ppm }\end{array}$ \\
\hline 1 & 0.53 & 0.011 & 1.11 & $<10$ \\
2 & 0.4 & 0.008 & 0.89 & $<10$ \\
3 & 0.47 & 0.009 & 0.81 & $<10$ \\
4 & 0.54 & 0.011 & 0.86 & $<10$ \\
5 & 0.49 & 0.0096 & 0.99 & $<10$ \\
\hline
\end{tabular}


total throughput of approximately $925 \mathrm{~mL} / \mathrm{min}$ the aqueous effluent became distinctly cloudy and some foam was observed on the upper surface of the aqueous effluent collected in sight glass G-A. When the flow rate was increased to $1015 \mathrm{~mL} / \mathrm{min}$, significant entrainment of organic solution in the aqueous effluent occurred.

Contamination-free operation was reestablished when the throughput was reduced to 895 $\mathrm{mL} / \mathrm{min}$. This throughput value is in very close agreement with results obtained in "cold" (nonradioactive) throughput tests performed in a separate test effort and reported elsewhere. ${ }^{4}$

\subsection{EXTRACTION-MODE IRRADIATION TEST}

\subsubsection{Phase-Separation Performance}

Data obtained from observations of dispersion settling in sight glass G-M under extraction conditions are listed in Table 7. As was the case under stripping conditions, phase separation timcs and dispersion numbers exhibit increased resistance to phase disengagement under gravity conditions. Again, considerable scatter in dispersion numbers is observed when replicate determinations were made at the same sampling interval. Despite the general trend, the dispersion values obtained over the course of the test are well above the limit for adequate phase separation in centrifugal contactors. ${ }^{3}$ Not surprisingly, effluents collected from contactor operations at each sampling interval exhibited no cross-phase contamination.

\subsubsection{Cesium Distribution Results}

Cesium distribution ratio values calculated from extraction-mode sample results are listed in Table 8 . The ratio values are generally high, particularly in light of the elevated temperatures present in the test loop (generally 30 to $32^{\circ} \mathrm{C}$ during contactor operation). A possible cause of inflated distribution ratio values is the evaporation of nonextractant solvent components, resulting in an increase in the extractant concentration. Given the extended duration of the test, a mixing tank temperature that ranged from approximately $31^{\circ}$ to $47^{\circ} \mathrm{C}$ during the irradiation, and the number of openings to atmosphere in the test system (liquid addition and sample points), evaporation of various liquid component could occur. However, assay results from samples collected during testing indicate no change in the solvent composition. Therefore, it seems more likely that high extraction-mode distribution ratios are the result of inaccuracies in aqueous sample analysis or in the calculations used to estimate the organic-phase cesium concentration. 


\subsubsection{Solvent Degradation Results-Extraction Testing}

In addition to the indication of no change in the concentrations of the solvent components, the analytical results from solvent samples collected during the extraction-mode irradiation test indicate no measurable formation of the modifier radiolysis product (see Table 9).

Table 7. Results from extraction-mode gravity settling observations

\begin{tabular}{cccccccc}
\hline $\begin{array}{c}\text { Sampling } \\
\text { interval }\end{array}$ & $\begin{array}{c}\text { Dispersion } \\
\text { volume } \\
(\mathrm{mL})\end{array}$ & $\begin{array}{c}\text { Solvent } \\
\text { volume } \\
(\mathrm{mL})\end{array}$ & $\begin{array}{c}\text { Aqueous } \\
\text { volume } \\
(\mathrm{mL})\end{array}$ & $\mathbf{O}$ A ratio & $\begin{array}{c}\text { Dispersion } \\
\text { band height } \\
(\mathrm{in})\end{array}$ & $\begin{array}{c}\text { Settling } \\
\text { time } \\
(\mathrm{s})\end{array}$ & $\begin{array}{c}\text { Dispersion } \\
\text { no. }\end{array}$ \\
\hline 1 & 428.78 & 104.6 & 324.0 & 0.32 & 3.87 & 55 & 0.001821 \\
1 & 437.4 & 95.9 & 341.5 & 0.28 & 3.95 & 57 & 0.001775 \\
2 & 411.2 & 95.9 & 315.3 & 0.30 & 3.72 & 86 & 0.001141 \\
2 & 433.0 & 104.6 & 328.4 & 0.32 & 3.91 & 70 & 0.001438 \\
3 & 433.0 & 104.6 & 328.4 & 0.32 & 3.91 & 100 & 0.001007 \\
4 & 415.6 & 100.3 & 315.3 & 0.32 & 3.76 & 140 & 0.000705 \\
5 & 411.2 & 95.9 & 315.3 & 0.30 & 3.72 & 135 & 0.000727 \\
\hline
\end{tabular}

Table 8. Cesium distribution results from the extraction-mode irradiation test

\begin{tabular}{ccccccccc}
\hline $\begin{array}{c}\text { Sample } \\
\text { ID }\end{array}$ & $\begin{array}{c}\text { Aqueous } \\
\text { phase } \\
(\mathrm{Ci} / \mathrm{L})\end{array}$ & $\begin{array}{c}\text { Sample } \\
\text { dilution }\end{array}$ & $\begin{array}{c}\text { Corrected } \\
\text { activity } \\
(\mathrm{Ci} / \mathrm{L})\end{array}$ & $\begin{array}{c}\text { Aqueous } \\
\text { system } \\
\text { volume } \\
(\mathrm{mL})\end{array}$ & $\begin{array}{c}\text { Solvent } \\
\text { volume } \\
(\mathrm{mL})\end{array}$ & $\begin{array}{c}\text { Total } \\
\text { aqueous } \\
\text { activity } \\
(\mathrm{Ci})\end{array}$ & $\begin{array}{c}\text { Total } \\
\text { solvent } \\
\text { activity } \\
(\mathrm{Ci})\end{array}$ & $\mathrm{D}_{\mathrm{Cs}}$ \\
\hline 1 & $6.76 \mathrm{E}-04$ & 100.0453 & $6.76 \mathrm{E}-02$ & 3270 & 990 & $2.21 \mathrm{E}-01$ & $1.62 \mathrm{E}+00$ & $2.42 \mathrm{E}+01$ \\
2 & $9.73 \mathrm{E}-04$ & 91.07047 & $8.86 \mathrm{E}-02$ & 3205 & 970 & $2.84 \mathrm{E}-01$ & $1.56 \mathrm{E}+00$ & $1.81 \mathrm{E}+01$ \\
3 & $1.35 \mathrm{E}-03$ & 127.7476 & $1.73 \mathrm{E}-01$ & 3240 & 950 & $5.59 \mathrm{E}-01$ & $1.28 \mathrm{E}+00$ & $7.81 \mathrm{E}+00$ \\
4 & $1.84 \mathrm{E}-03$ & 66.63638 & $1.22 \mathrm{E}-01$ & 3175 & 930 & $3.89 \mathrm{E}-01$ & $1.45 \mathrm{E}+00$ & $1.27 \mathrm{E}+01$ \\
5 & $9.73 \mathrm{E}-04$ & 94.0358 & $9.15 \mathrm{E}-02$ & 3110 & 910 & $2.85 \mathrm{E}-01$ & $1.56 \mathrm{E}+00$ & $1.87 \mathrm{E}+01$ \\
\hline
\end{tabular}


Table 9. Analytical results for solyent samples from extraction-mode irradiationtest

\begin{tabular}{ccccc}
\hline $\begin{array}{c}\text { Sample } \\
\text { Interval }\end{array}$ & $\begin{array}{c}\text { Cs-7SB } \\
\text { (modifier) } \\
\text { concentration } \\
(M)\end{array}$ & $\begin{array}{c}\text { BOBCalixC6 } \\
\text { concentration } \\
(M)\end{array}$ & $\begin{array}{c}\text { Trioctylamine } \\
\text { concentration } \\
(m M)\end{array}$ & $\begin{array}{c}\text { 4-sec-butylphenol } \\
\text { concentration } \\
(\mathrm{ppm})\end{array}$ \\
\hline 1 & 0.47 & 0.0092 & 1.02 & $<10$ \\
2 & 0.53 & 0.011 & 0.98 & $<10$ \\
3 & 0.55 & 0.011 & 1.01 & $<10$ \\
4 & 0.57 & 0.012 & 0.95 & $<10$ \\
5 & 0.57 & 0.011 & 0.86 & $<10$ \\
\hline
\end{tabular}

\subsubsection{Maximum Throughput Determination Using Irradiated Solvent- Extraction Condition}

At the end of the extraction-mode irradiation test, the flow to the centrifugal contactor was increased incrementally from the baseline, extraction test condition of $800 \mathrm{~mL} / \mathrm{min}$ to determine maximum capacity. Contactor rotation was maintained at $3600 \mathrm{rpm}$ throughout this phase of testing. With the pump speed controller at its maximum setting, cross-phase contamination was not found in either of the contactor effluent streams. The flow rate was verified at the maximum pump setting and was found to be $1092 \mathrm{~mL} / \mathrm{min}$. This result is consistent with results obtained in out-of-cell tests performed using cold cesium. ${ }^{4}$

\section{CONCLUSIONS}

The results from internal irradiation testing under both extraction and stripping conditions indicate a general trend toward poorer phase separation by gravity settling. However, variations between dispersion numbers determined from replicate data sets are indicative of the difficulty in consistently determining the precise point at which the two dispersed phases are separated, particularly when the observations are made through a hot-cell window. The gravity settling trend notwithstanding, effluent samples collected from the $5-\mathrm{cm}$ centrifugal contactor at all sampling intervals were consistently free of cross-phase contamination. This finding indicates that, when solvent radiation exposure is limited to that expected in 2 years of CSSX operation, the 
phase-separation capability of a $5-\mathrm{cm}$ centrifugal contactor operating at $3600 \mathrm{rpm}$ is robust enough to accommodate minor, adverse changes in phase-separation behavior.

Distribution ratio values obtained under extraction conditions were quite high, particularly when elevated-temperature conditions in the test loop are taken into consideration. However, the $\mathrm{D}_{\mathrm{Cs}}$ values reported for both extraction and stripping conditions must be reviewed in the context of the experimental procedure. Because of the imprecision in the withdrawal of samples and the manner in which organic-phase ${ }^{137} \mathrm{Cs}$ concentrations were calculated (i.e., by difference), the distribution ratio values reported have significant error bands.

The analytical and assay results for the CSSX solvent indicate no change in the solvent composition and no formation of 4-sec-butylphenol, within the error range and detection limits of the analysis methods.

The overall conclusion to be drawn from the body of data collected and observations made during the tests reported here is that no significant change in phase-separation performance is to be expected in a contactor-based CSSX process in which solvent is retained for a period of 2 years.

\section{REFERENCES}

1. P.V. Bonnesen, L. H. Delmau, T. J. Haverlock, and B. A. Moyer, Alkaline-Side Extraction of Cesium from Savannah River Tank Waste Using a Calixarene-Crown Ether Extractant, Oak Ridge National Laboratory Report ORNL/TM-13704, Oak Ridge, Tennessee, 1998.

2. R. A. Peterson, Preparation of Simulated Waste Solutions for Solvent Extraction Testing, WSRC-RP-2000-00361, Savannah River Technology Center, Aiken, South Carolina, May 2000 .

3. R. A. Leonard, "Design Rules for Solvent Extraction," Solvent Extr. Ion Exch. 17(3), 597612 (1999).

4. J. F. Birdwell and K.K. Anderson, Evaluation of 5 -cm Centrifugal Contactor Hydraulic and Mass Transfer Performance for Caustic-SideSolvent Extraction of Cesium, Oak Ridge National Laboratory, Oak Ridge, Tennessee, in preparation. 


\section{APPENDIX}

CSSX cascade cesium concentration profile calculations 


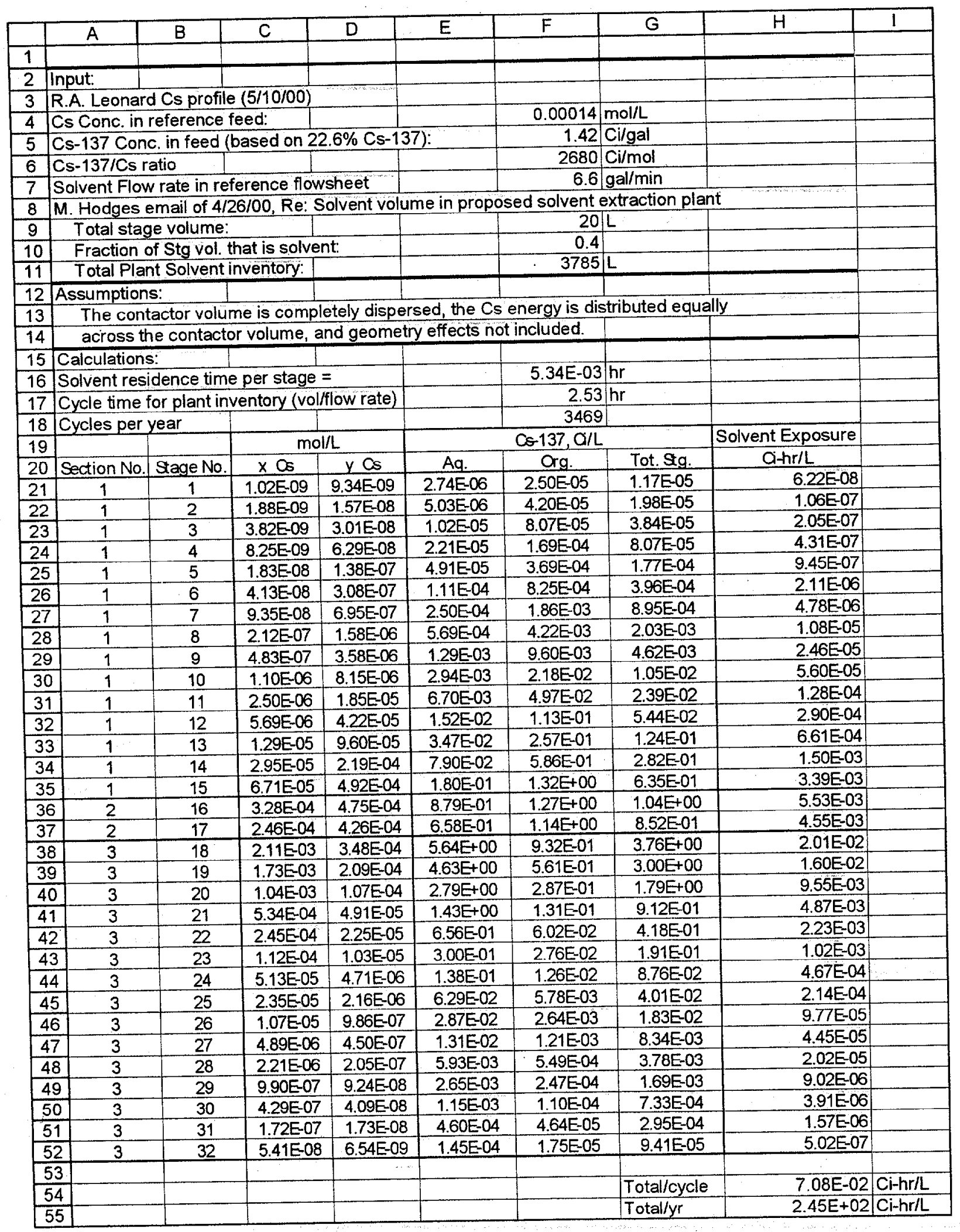




\section{INTERNAL DISTRIBUTION}

1. K. K. Anderson

2-3. J. F. Birdwell, Jr.

4. P. V. Bonnesen

5. J. L. Collins

6. R. L. Cummins

7. L. H. Delmau

8. J. N. Herndon

9. R. D. Hunt

10. R. T. Jubin

11. T. E. Kent

12-15. L. N. Klatt

16. D. D. Lee

17. M. P. Maskarinec

18. A. Mattus

19. C. P. McGinnis

20. L. E. McNeese

21. B. A. Moyer

22. K. E. Plummer

23. F. V. Sloop, Jr.

24. R. D. Spence

25. B. B. Spencer

26. J. F. Walker

27. J. S. Watson

28. ORNL Central Research Library

29. Laboratory Records, RC

30. Laboratory Records, OSTI

\section{EXTERNAL DISTRIBUTION}

31. J. T. Carter, Westinghouse Savannah River Company, P.O. Box 616, Buidling 704-3B, Aiken, SC 29808

32. D. Chamberlain, Argonne National Laboratory, Building 205, 9700 South Cass Avenue, Argonne, IL 60439

33. N. F. Chapman, Westinghouse Savannah River Company, P.O. Box 616, Buidling 704-3B, Aiken, SC 29808

34. C. Conner, Argonne National Laboratory, Building 205, 9700 South Cass Avenue, Argonne, IL 60439

35. R. G. Edwards, Westinghouse Savannah River Company, P.O. Box 616, Buidling 704-3B, Aiken, SC 29808

36. S. D. Fink, Westinghouse Savannah River Company, P.O. Box 616, Building 773-A, Aiken, SC 29808 
37. H. D. Harmon, Tank Focus Area Salt Processing Program, P.O. Box 616, Building 704-3N, Aiken, SC 29808

38. R. T. Jones, Westinghouse Savannah River Company, P.O. Box 616, Building 704-3N, Aiken, SC 29808

39. R. A. Leonard, Argonne National Laboratory, Building 205, 9700 South Cass Avenue, Argonne, IL 60439

40. J. W. McCullough, Jr., U.S. Department of Energy, Savannah River Operations Office, Bldg. 704-3N, Aiken, SC 29808

41. J. R. Noble-Dial, U.S. Department of Energy, Oak Ridge Operations Office, P.O. Box 2001, Oak Ridge, TN $37831-8620$

42. Michael Norato, Westinghouse Savannah River Company, P.O. Box 616, Building 773-A, Aiken, SC 29808

43. Robert Pierce, Westinghouse Savannah River Company, P.O. Box 616, Building 773-A, Aiken, SC 29808

44. S. N. Schlahta, Tank Focus Area Salt Processing Program, P. O. Box 616, Building 704-3N, Aiken, SC 29808

45. P. C. Suggs, U.S. Department of Energy, Savannah River Operations Office, P.O. Box A, Building 704-3N, Aiken, SC 29808

46. W. L. Tamosaitis, Westinghouse Savannah River Company, P.O. Box 616, Building 773-A, Aiken, SC 29808

47. M. Thompson, Westinghouse Savannah River Company, P.O. Box 616, Building 773-A, Aiken, SC 29808

48. T. A. Todd, Idaho National Engineering \& Environmental Laboratory, Building 637, MS5218, Idaho Falls, ID 834415-5218

49. G. Vandegrift, Argonne National Laboratory, Building 205, 9700 South Cass Avenue, Argonne, IL 60439

50. Doug Walker, Westinghouse Savannah River Company, P.O. Box 616, Building 773-A, Aiken, SC 29808

51. Dennis Wester, Westinghouse Savannah River Company, P.O. Box 616, Building 773-A, Aiken, SC 29808

52. W. R. Wilmarth, Westinghouse Savannah River Company, P.O. Box 616, Building 773-A, Aiken, SC 29808

53. Tanks Focus Area Technical Team, c/o B. J. Williams, Pacific Northwest National Laboratory, P.O. Box 999, MSIN K9-69, Richland, WA 99352 
54. Tanks Focus Area Field Lead, c/o T. P. Pietrok, U.S. Department of Energy, Richland Operations Office, P.O. Box 550, K8-50, Richland, WA 99352

55. Tanks Focus Area Headquarters Program Manager, c/o K. D. Gerdes, DOE Office of Science and Technology, 19901 Germantown Rd., 1154 Cloverleaf Building, Germantown, MD 20874- 1290 